\title{
Inorganic As speciation and bioavailability in estuarine sediments of Todos os Santos Bay, BA, Brazil
}

\author{
V. Hatje ${ }^{\mathrm{a}, \mathrm{c}, *}$, S.M. Macedo ${ }^{\text {b,c }}$, R.M. de Jesus ${ }^{\mathrm{b}, \mathrm{c}, \mathrm{d}}$, G. Cotrim ${ }^{\mathrm{a}}$, K.S. Garcia ${ }^{\mathrm{e}}$, A.F. de Queiroz ${ }^{\text {e }}$, S.L.C. Ferreira ${ }^{\text {b,c }}$ \\ ${ }^{a}$ Laboratório de Oceanografia Química, Instituto de Química, UFBA, Campus Ondina, Salvador, BA, 40170-290, Brazil \\ b Instituto de Ouímica, UFBA, Campus Ondina, Salvador, BA, 40170-290, Brazil \\ ' Instituto Nacional de Ciência e Tecnologia, INCT, de Energia e Ambiente, UFBA, Salvador, BA, 40170-290, Brazil \\ ${ }^{\mathrm{d}}$ Departamento de Ciências Exatas e Tecnológicas, Universidade Estadual de Santa Cruz, Ilhéus, BA, 45650-000, Brazil \\ ${ }^{\mathrm{e}}$ Departamento de Geoquímica, Universidade Federal da Bahia, BA, 45650-000, Brazil
}

\section{A R T I C L E I N F O}

\section{Keywords:}

Speciation

Arsenic

Paraguaçu River

Subaé River

Jaguaripe River

Slurry sampling

\begin{abstract}
A B S T R A C T
The spatial distribution of As (total As, As (III) and As (V)) in estuarine sediments from the main tributaries of Todos os Santos Bay, BA, Brazil, was evaluated under high and low flow conditions. The concentrations of As were determined using a slurry sampling procedure with hydride generation atomic absorption spectrometry (HG-AAS). The highest concentrations were observed at estuary mouths, and exceeded conservative lower threshold value (Threshold Effects Level; TEL). Due to the oxic conditions and abundance of $\mathrm{Mn}$ and Fe (oxyhydr)oxides in the sediments, most inorganic arsenic in the Subaé and Paraguaçu estuaries was present as As (V). Nevertheless, the concentration of As (III) at several locations along the Jaguaripe River were also above the TEL value, suggesting that As may be toxic to biota. In the Subaé estuary, antropogenic activities are the main source of As. At the Jaguaripe and at Paraguaçu estuaries, nevertheless, natural sources of As need to be considered to explain the distribution patterns. (c) 2010 Elsevier Ltd. All rights reserved.
\end{abstract}

\section{Introduction}

In aquatic environments, arsenic occurs in both organic and inorganic forms. Inorganic forms of arsenic consist primarily of arsenite (As (III)) and arsenate (As (V)) compounds, while there are many organic forms of arsenic, including monomethylersonic acid (MMA) and dimethylarsonic acid (DMA) (Ko et al., 2004; Plant et al., 2005). Depending on the geochemical environment ( $\mathrm{pH}$, redox conditions, organic matter, etc.), arsenic can exist in four oxidation states, namely, $-3,0,+3$ and +5 . However, environmental exposure often occurs through As (III) and As (V) (Hughes, 2002), which are highly toxic and lead to a wide range of health problems in humans. As (V) sorbs more strongly to minerals than As (III); thus, As (V) is slightly less toxic and less mobile (Pierce and Moore, 1982). However, both As (III) and As (V) are carcinogenic, mutagenic and teratogenic (National Research Council, 1999). Many cases of acute and chronic arsenic poisoning have been reported in various parts of the world (Gray et al., 1989; WHO, 1993; Senesse et al., 1999; Saha, 2003). Arsenic is the number one toxin on the US Environmental Protection Agency's list of prioritised

\footnotetext{
* Corresponding author at: Laboratório de Oceanografia Química, Instituto de Química, UFBA, Campus Ondina, Salvador, BA, 40170-290, Brazil. Tel./fax: +55 71 32355166.

E-mail address: vhatje@ufba.br (V. Hatje).
}

pollutants, and it is a public concern due to its widespread usage in both agriculture and industry (USEPA, 1998).

Naturally occurring As in aquatic environments originates from the weathering of primary and secondary minerals (Datta et al., 2007). Arsenic occurs as a major constituent in more than 200 minerals. Approximately $60 \%$ of arsenic minerals are arsenates, $20 \%$ sulfides and sulfosalts, and the remaining $20 \%$ are arsenides, arsenites, oxides, alloys and polymorphs of elemental As (Plant et al., 2005). The most abundant As ore mineral is arsenopyrite, FeAsS (Tomkins et al., 2006). It is generally accepted that arsenopyrite, together with the other dominant As-sulfide minerals realgar and orpiment, are only formed under high temperature conditions in the earth's crust. However, authigenic arsenopyrite has been reported in sediments by Rittle et al. (1995).

Anthropogenic activities have progressively accelerated the transfer of arsenic from the geosphere to the surface environment and have distributed arsenic throughout the biosphere (Plant et al., 2005). Anthropogenic activities that alter the natural biogeochemical cycle of As include mining, smelting, combustion of coals, refining of fossil-fuels, use of biocides such as wood preservatives and pesticides, waste incineration, and the manufacturing and use of feed additives.

The total arsenic concentration in sediments and water depends first on the local geology, and then on potential anthropogenic inputs. However, because the toxicity, mobility and availability of arsenic rely on its chemical form, quantitative analyses and 
speciation studies are necessary. To evaluate the toxicity and bioavailability of As, samples from the region of interest are often extracted with water, dilute acetic acid or EDTA. It is crucial to determine the bioavailability, once it is a relative measure of the fraction of the total metal that an organism actually can takes up from all possible sources, including water, sediments and food (Luoma and Rainbow, 2008). Sequential extractions, carried out by the sequential use of reagents with different chemical properties, are also frequently employed to estimate bioavailability and toxicity. The procedures developed by Tessier et al. (1979) and Quevauviller et al. (1994) are the most widely used sequential extractions to study coastal sediments; however, a limited number of studies on the determination of As from estuarine sediments have been conducted (Matera et al., 2003; Giacomino et al., 2010).

Problems associated with sample preparation, lixiviation and/or decomposition are frequently encountered in the determination of trace elements. Moreover, some arsenic species are volatile, and acid digestions must be performed in a closed system to reduce losses (Costa et al., 2009). Currently, solid sampling is the preferred technique for arsenic determination in solid matrices due to the complete elimination of a sample pre-treatment step (Vale et al., 2006). However, this technique requires specialised instrumentation that is not always available. Slurry sampling (Cal-Pietro et al., 2002; Santos and Nóbrega, 2006) is an excellent alternative, eliminating the need for a sample pre-treatment step and reducing the risk of analyte loss or contamination. Due to the advantages of slurry sampling, several methods for the determination of arsenic in environmental matrices have been proposed (e.g. Macedo et al., 2009).

The objective of this work was to characterize the spatial distribution of Total As and the inorganic As species along the three main tributaries of Todos os Santos Bay, BA, Brazil, during the wet and dry season, employing slurry sampling (SS) and hydride generation atomic absorption spectrometry (HG-AAS). Improved knowledge of the distribution and speciation of arsenic will enhance the understanding of As toxicity and bioavailability.

\section{Methods}

\subsection{Study area}

Todos os Santos Bay (BTS) is centred at $12^{\circ} 50^{\prime}$ S latitude and $38^{\circ} 38^{\prime} \mathrm{W}$ (Fig. 1) longitude, and possesses a maximum width and length of $32 \mathrm{~km}$ and $50 \mathrm{~km}$, respectively. BTS is located in the vicinity of Salvador, the third largest metropolitan area of Brazil, and the home of the largest petrochemical complex in the southern hemisphere. Several anthropogenic activities influence the system's environmental quality, such as the influx of domestic effluents, solid wastes, agriculture, industrial (chemicals, petrochemicals, smelters, etc.) and mining activities (CRA, 2008; Hatje and de Andrade, 2009). As a result, relatively high concentrations of trace elements and hydrocarbons (HPAs) are observed in marine invertebrates (Wallner-Kersanach et al., 2000; CRA, 2004; Amado Filho et al., 2008; Santil, 2010; Hatje et al., 2009), sediments (CRA, 2004; Venturini et al., 2004; Hatje et al., 2006; Barros et al., 2008; Venturini et al.; 2008; Hatje et al., 2009), and atmospheric particles (Pereira et al., 2007; da Rocha et al., 2009), especially in the northern region.

The Paraguaçu, Subaé and Jaguaripe River (Fig. 1) are the three main tributaries of the BTS. The catchment of the Paraguaçu River is $56,300 \mathrm{~km}^{2}$, and downstream of the Pedra do Cavalo Dam, Paraguaçu presents an average discharge of $64 \mathrm{~m}^{3} \mathrm{~s}^{-1}$ (Genz, 2006). Maximum flows are observed in summer months, especially in December-January. The other two main catchments of the BTS are the Jaguaripe $\left(2200 \mathrm{~km}^{2}\right)$ and Subae River $\left(600 \mathrm{~km}^{2}\right)$. The maximum discharge of the Jaguaripe and Subaé River occurs in June (winter), where a mean monthly discharge of $28 \mathrm{~m}^{3} \mathrm{~s}^{-1}$ and $9 \mathrm{~m}^{3} \mathrm{~s}^{-1}$ is observed, respectively (Cirano and Lessa, 2007).

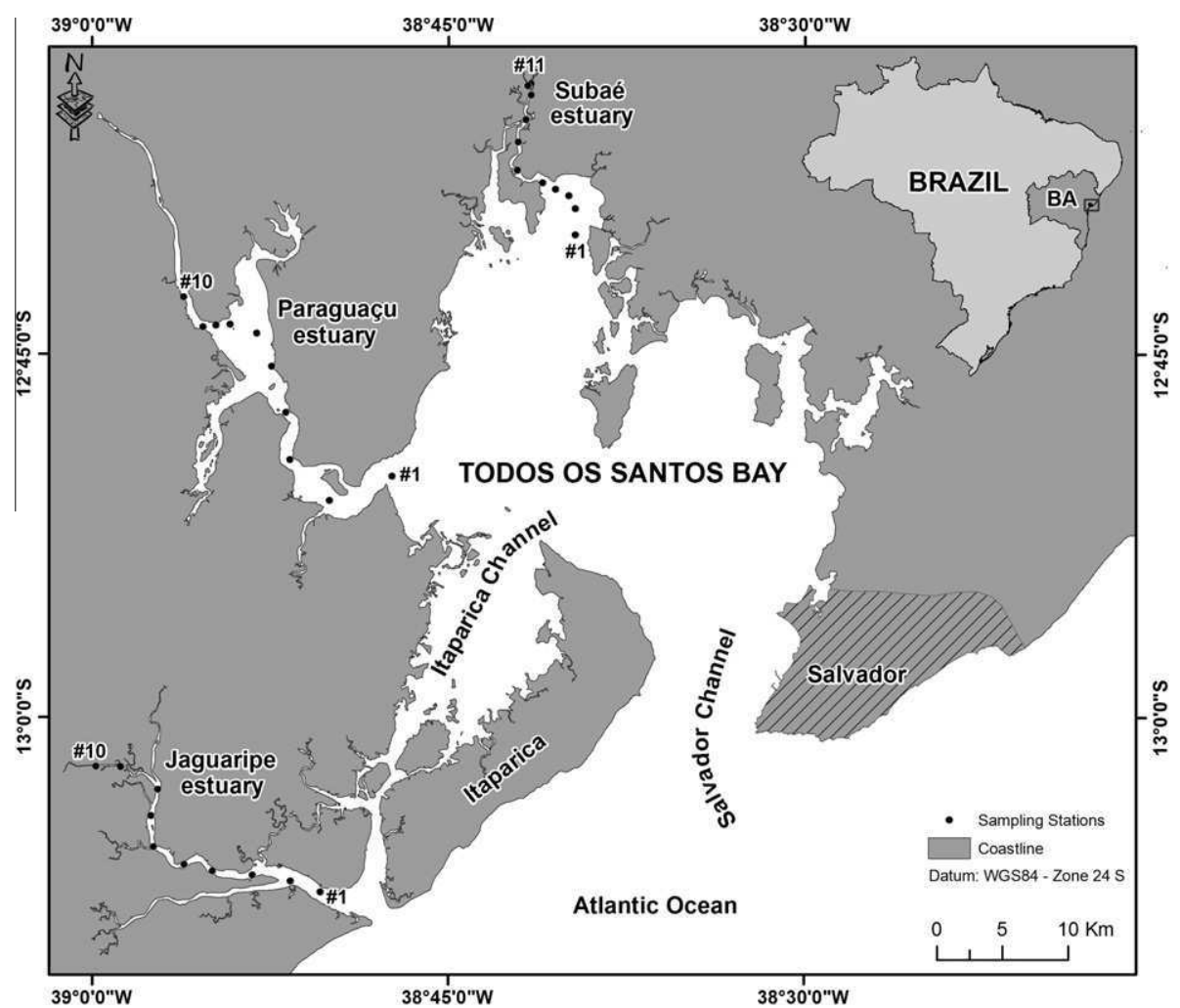

Fig. 1. Sampling sites located along the tributaries of Todos os Santos Bay, Bahia, Brazil. 


\subsection{Sampling}

Two campaigns were conducted at the Paraguaçu, Subaé and Jaguaripe estuaries (Fig. 1) between 2003 and 2007, in which data were collected during both the wet and dry seasons. In this study, salinity, temperature and the concentration of dissolved oxygen and suspended particulate matter (SPM) were measured at each sampling site, and sediment was collected from 10-11 stations located on the main channel of each estuary. Physico-chemical variables were measured with a water quality analyser (Datasonda Hydrolab 4A) that was calibrated prior to field work. Sediment samples from the Subaé and Jaguaripe River were collected by SCUBA divers. A PVC core with a diameter of $5 \mathrm{~cm}$ was dragged horizontally for $2 \mathrm{~m}$ through surface sediments $(1-5 \mathrm{~cm}$ ) (Hatje et al., 2006). Once the sample was collected, the core was capped and the tube retrieved. Sediment samples from the Paraguaçu River were collected with a Van Veen dredge, and a portion of the surface sediment was collected from the centre of the dredge (Barros et al., 2008). Samples were transferred to a pre-cleaned LDPE container and were frozen until the analyses were conducted. Redox and $\mathrm{pH}$ measurements were obtained with a combined electrode (Thermo Oriun Model 630). All bottles and materials used for the collection and analysis of samples were cleaned by soaking the materials for $24 \mathrm{~h}$ in a solution of detergent (Extran 2\%) that was placed in a covered tank. The materials were rinsed with deionised water (DI; $18 \mathrm{M} \Omega \mathrm{cm}^{-1}$ resistivity) and soaked in $10 \%$ nitric acid for at least $48 \mathrm{~h}$. Finally, the bottles were rinsed three times with DI water and were stored in two polyethylene bags. Gloves were worn throughout all of the procedures.

\subsection{Sample preparation and analytical methods}

Sediment samples were divided into two parts, with one portion of the sediment used to determine the particle size distribution and the other used for chemical analyses. Before the analyses were conducted, the sediments were wet sieved to isolate the material that was less than $63 \mu \mathrm{m}$, and this fraction was used in trace element analyses. Sediment samples were freeze-dried and comminuted with a ball mill.

Sediment slurries were prepared by combining $0.1 \mathrm{~g}$ of dry sample with $3.0 \mathrm{~mL}$ of $6.0 \mathrm{~mol} \mathrm{~L}^{-1}$ hydrochloric acid in a $25 \mathrm{~mL}$ flask and immersing the suspension in an ultrasonic bath for $30 \mathrm{~min}$. Upon completion, the slurries were diluted to a total volume of $25 \mathrm{~mL}$ with Milli-Q water. All reagent blanks were prepared according to the same procedure as the sample slurries. Aqueous standards were used to generate standard calibration curves.

To determine the total arsenic concentration, $3.33 \mathrm{~mL}$ of $6 \mathrm{~mol} \mathrm{~L}^{-1}$ hydrochloric acid, $1 \mathrm{~mL}$ of pre-reducing solution $(10 \%$ $\mathrm{KI}$ and $2 \%$ ascorbic acid) and aliquots of the slurries were added to the reaction flasks. After $30 \mathrm{~min}$, the resultant solutions were diluted to $10 \mathrm{~mL}$ with Milli-Q water. With a peristaltic pump, sodium tetrahydroborate was introduced into the closed system at a rate of $2.70 \mathrm{~mL} \mathrm{~min}^{-1}$. The arsine vapour generated by the reaction was transported to the AA spectrometer (Macedo et al., 2009) under a flow of argon at a rate of $100 \mathrm{~mL} \mathrm{~min}^{-1}$.

Calibration curves were generated by processing aqueous standards and the absorbance was a linear function of the arsenic concentration in the range of $0.3-5.0 \mu \mathrm{g} \mathrm{L}^{-1}$ for total arsenic and $0.5-$ $5.0 \mu \mathrm{g} \mathrm{L}^{-1}$ for As (III).

To determine the concentration of arsenic (III), aliquots of the sample slurries were transferred to reaction flasks containing $2 \mathrm{~mL}$ of citric acid/sodium citrate buffer solution and were diluted to a final volume of $10 \mathrm{~mL}$ with Milli-Q water. Using a peristaltic pump, sodium tetrahydroborate was introduced into the closed system at a rate of $2.70 \mathrm{~mL} \mathrm{~min}^{-1}$, and the arsine vapour generated by the reaction was transported to the AA spectrometer under a flow of argon at a rate of $100 \mathrm{~mL} \mathrm{~min}^{-1}$. Arsenic concentrations were measured by an atomic absorption spectrometer with an arsenic hollow cathode lamp (Varian model SpectrAA 220, Mulgrave, Victoria, Australia), and atomisation was achieved in a quartz tube heated with an air-acetylene flame. The absorption wavelength was set to $193.7 \mathrm{~nm}$, and measurements were made with a lamp current of $10 \mathrm{~mA}$ and a slit width of $0.5 \mathrm{~nm}$. A deuterium lamp was used for background corrections, and the flame was composed of acetylene $\left(2.0 \mathrm{~L} \mathrm{~min}^{-1}\right)$ and air $\left(13.5 \mathrm{~L} \mathrm{~min}^{-1}\right)$. An Alitea C-6 XV peristaltic pump (Stockholm, Sweden) equipped with Tygon tubing was used to propel the solutions. High purity (99.99\%) argon at a flow rate of $100 \mathrm{~mL} \mathrm{~min}^{-1}$ was used as a purge gas. To determine the arsenic concentration, a quartz T-tube cell with a path length of $165 \mathrm{~mm}$ and a diameter of $12 \mathrm{~mm}$ was heated to approximately $900{ }^{\circ} \mathrm{C}$.

The detection and quantification limits were calculated according to IUPAC recommendations (1994). The results indicated that the lower detection limit of total arsenic and As (III) was 0.1 and $0.3 \mu \mathrm{g} \mathrm{L}^{-1}$, respectively. The precision of the method was obtained by calculating the relative standard deviation $(\mathrm{RSD}=4.3 \%$ ) of the results obtained from a standard solution $\left(0.3 \mu \mathrm{g} \mathrm{L}^{-1}\right)$ over ten replicates. Each sediment sample was pre-treated and analysed in triplicates. For each set of samples, the accuracy of the analytical technique was assessed by determining the As concentration of certified reference materials (MESS-2 and MESS-3, National Research Council of Canada). The total As concentration of MESS- 2 and MESS-3 were $20.5 \pm 1.2 \mathrm{mg} \mathrm{kg}^{-1}$ and $20.2 \pm 0.5 \mathrm{mg} \mathrm{kg}^{-1}$, and the As (III) concentration was $5.4 \pm 0.4 \mathrm{mg} \mathrm{kg}^{-1}$ and $8.7 \pm 0.1 \mathrm{mg} \mathrm{kg}^{-1}$, respectively. The precision, expressed as the relative standard deviation (\%RSD), was less than $9.1 \%$. All procedures including sample collection were carefully undertaken to reduce contamination.

\section{Results and discussion}

\subsection{Environmental characteristics}

The well-oxygenated waters of the Paraguaçu and Jaguaripe estuaries displayed low turbidity, and the concentration of suspended solids ranged between 2.56 and $23.5 \mathrm{mg} \mathrm{kg}^{-1}$ and 4.0 and $79.1 \mathrm{mg} \mathrm{kg}^{-1}$, respectively. The salinity (Fig. 2) and the suspended solids concentration varied between sampling dates due to seasonal changes in precipitation and fluvial influx of freshwater. The temporal effects in salinity, turbidity and fluvial influx have been discussed by Genz (2006) and Cirano and Lessa (2007). The salinity and the concentration of total suspended solids in the Jaguaripe estuary during the dry season were higher than expected. During the dry season, weather conditions at the catchment area of Jaguaripe were atypical, which resulted in anomalous physical-chemistry characteristics for this time of the year, as shown in the salinity profiles presented in Fig. 2.

The oxygen concentration of Subaé river water was lower than the oxygen concentration of the other estuaries. The lowest oxygen concentrations $\left(2.71 \mathrm{mg} \mathrm{L}^{-1}\right)$ were observed at upstream sampling sites during the dry season (Fig. 1; stations 8-11) due to large inputs of untreated sewage and industrial waste. At several sites along the river, the direct discharge of domestic effluents was observed. This region has a chronic $\mathrm{Pb}, \mathrm{Zn}$ and $\mathrm{Cd}$ contamination problem associated with an inactive lead smelter, as previously described (e.g. Reis, 1975; CRA, 2004; Hatje et al., 2006; Hatje et al., 2009). The concentration of suspended particulate material in the Subaé River varied between 6.23 and $86.6 \mathrm{mg} \mathrm{kg}^{-1}$. Although these values were similar to those observed in the Jaguaripe, it has been reported that the Subaé is the principal source of suspended material for the BTS (CRA, 2004; Hatje et al., 2006; Cirano and Lessa, 2007). The Subaé estuary is one of the most contaminated regions 

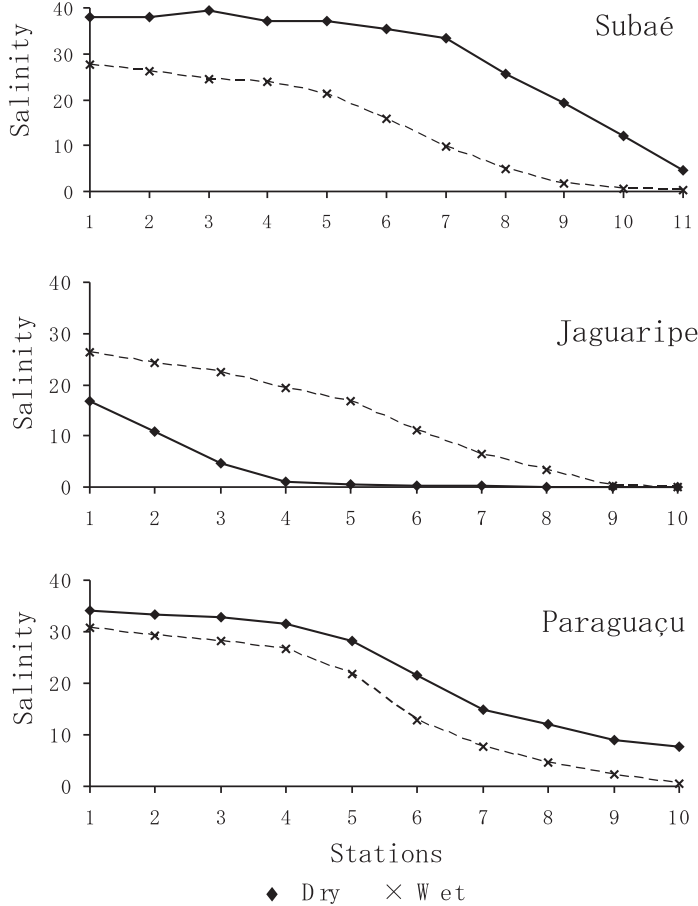

Fig. 2. Superficial water salinity profiles of the tributaries of Todos os Santos bay, Bahia, Brazil.

of Todos os Santos Bay (Hatje et al., 2006; CRA, 2008; Hatje et al., 2009) and represents an important vector for the transport and distribution of contaminated particles to the main water body and sediments of the BTS.

Although a pronounced salinity gradient was observed, the $\mathrm{pH}$ of the water did not vary significantly within each estuary. In the Subaé, Jaguaripe and Paraguaçu River, the $\mathrm{pH}$ varied between 6.91 and $8.33,6.69$ and 7.89 , and 7.22 and 7.90, respectively. A significant correlation between the $\mathrm{pH}$ and the concentration of oxygen was not observed, which would be expected if primary production were an important factor controlling these variables. Studies have shown that the BTS, as well as the coast of Bahia, are oligotrophic systems (CRA, 2004; PETROBRAS/FUNDESPA, 2003).

The $\mathrm{pH}$ and $\mathrm{Eh}$ of the sediments (i.e., interstitial waters) in the Paraguaçu, Subaé and Jaguaripe River are shown in Fig. 3. In general, the $\mathrm{pH}$ of the sediments ranged from neutral to basic. Low acidic conditions were observed at a few sites on the Jaguaripe and Subaé River due to a large influx of organic matter from man- groves and untreated sewage. Geochemical conditions in the estuary sediments, as well as the BTS sediments (CRA, 2004), are primarily oxic, which is characteristic of an environment with low sulfide concentrations.

Sand was the dominant grain size in all of the studied tributaries (Fig. 4). In the Jaguaripe estuary, sand represented more than $90 \%$ of all sediment samples. The Paraguaçu and Subaé River presented similar grain size distributions, whereas the majority of upstream sites were dominated by sand, fine particles represented a significant portion of downstream sediments. The large variation in grain size along and between the estuaries justified the standardisation of grain size prior to chemical analyses.

\subsection{Total arsenic concentration}

Fig. 5 displays the total concentration of As in the estuarine sediments. The results indicated that the total concentration of As was significantly different between estuaries. Arsenic concentrations at Jaguaripe estuary, especially sites close to the mouth of the estuary, were significantly higher than the other areas. In fact, these sediments possessed As concentrations that were greater than those typically found in sedimentary rocks (Webster, 1999). The typical arsenic concentration of uncontaminated sediment varies between 6 and $100 \mathrm{mg} \mathrm{kg}^{-1}$, with a median concentration of $68 \mathrm{mg} \mathrm{kg}^{-1}$ (Ollson, 1999). According to the CRA (2004), the estimated concentration range of background As in the BTS varies between 5 and $17 \mathrm{mg} \mathrm{kg}^{-1}$, which is within global background values. The highest concentrations found at Jaguaripe estuary were almost two times greater than the upper limit of As background concentrations. High concentrations of As were unexpected in this region because the basin catchment of this estuary is relatively well-preserved, subjected to limited anthropogenic pressure (Hatje et al., 2009) and present a free communication with the open sea (Fig. 1). Arsenic concentrations between the Threshold Effect Level (TEL - $7.24 \mathrm{mg} \mathrm{kg}^{-1}$; NOAA, 2004) and the Probable Effect Level (PEL - $41.6 \mathrm{mg} \mathrm{kg}^{-1}$; NOAA, 2004) suggested that sediments at the mouth of the estuaries may be imposing toxicity to the most sensitive species. It is important to note, however, that sediment threshold values, such us TEL and PEL, are used only for screening purposes, i.e. to help portray concentrations which have been associated with probabilities of adverse biological effects. Moreover, the concentrations observed in this study are much lower than the As concentrations observed in other areas of the world (Gault et al., 2003; Razo et al., 2004; Zheng et al., 2003; Chapagain et al., 2009).

The distribution pattern of As was not correlated to the grain size of the sediments. For instance, in Jaguaripe estuary, As concentrations showed a marked increase from station 5 to station 1 (i.e.,
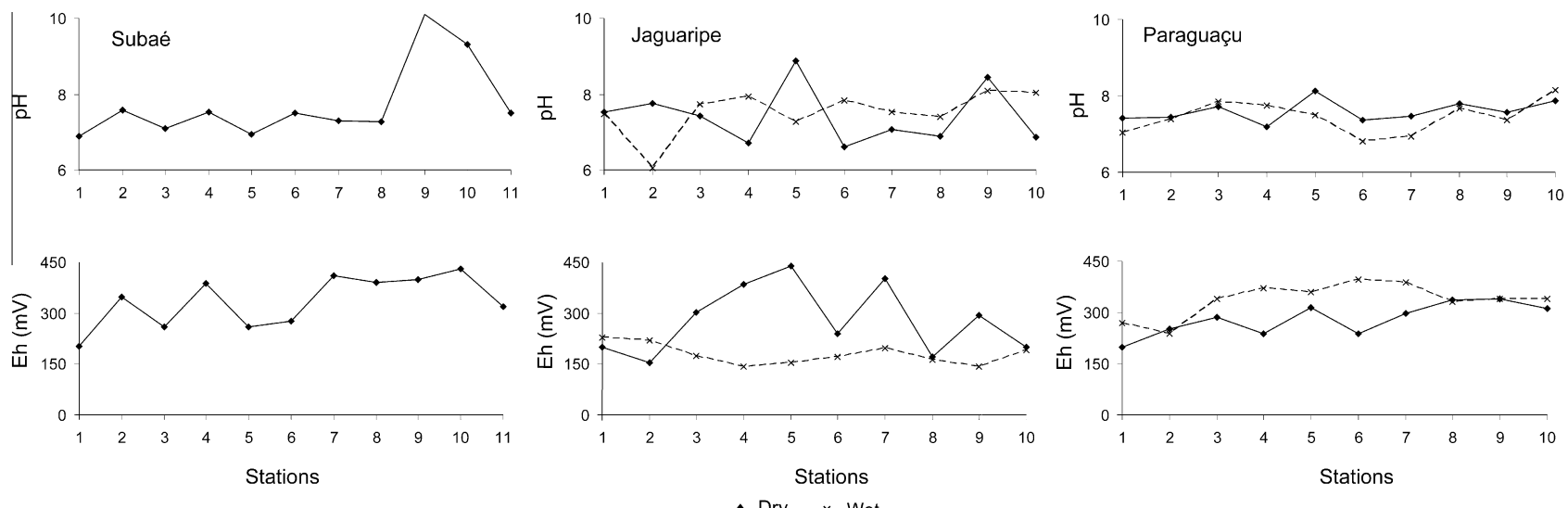

Fig. 3. The $\mathrm{pH}$ and Eh of sediments located in Todos os Santos bay tributaries, Bahia, Brazil. 

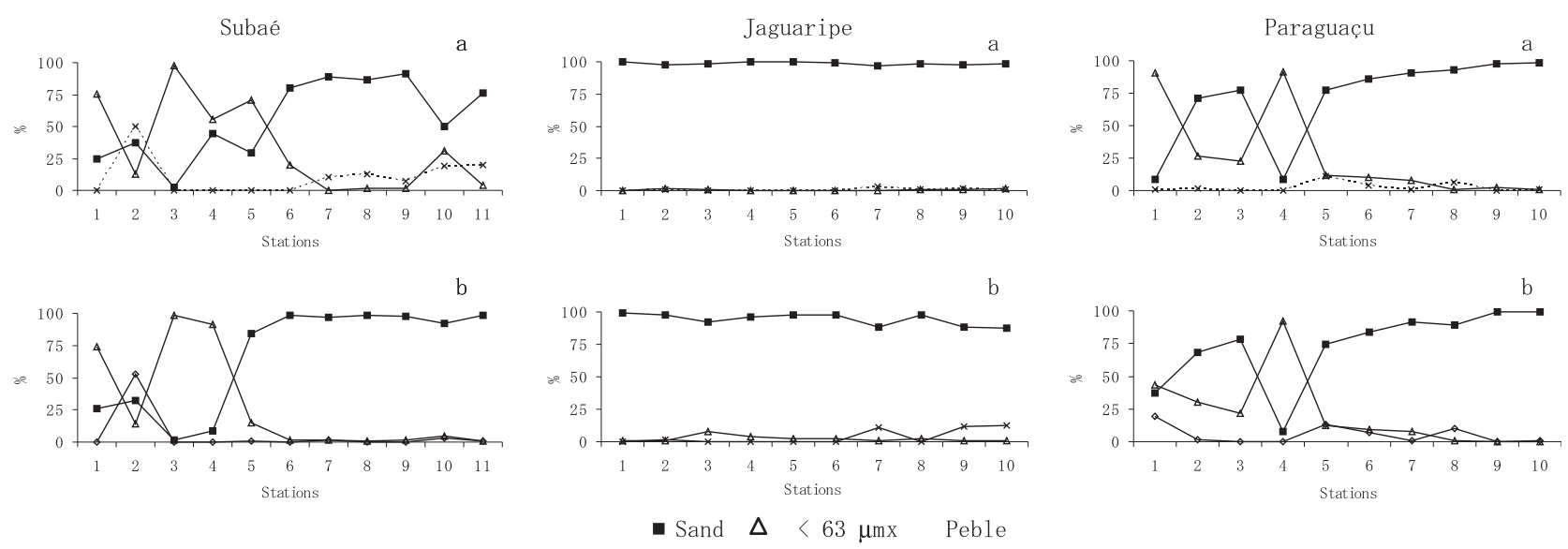

Fig. 4. Grain size distribution of sediments located in Todos os Santos bay tributaries, Bahia, Brazil, under (a) dry and (b) wet conditions.
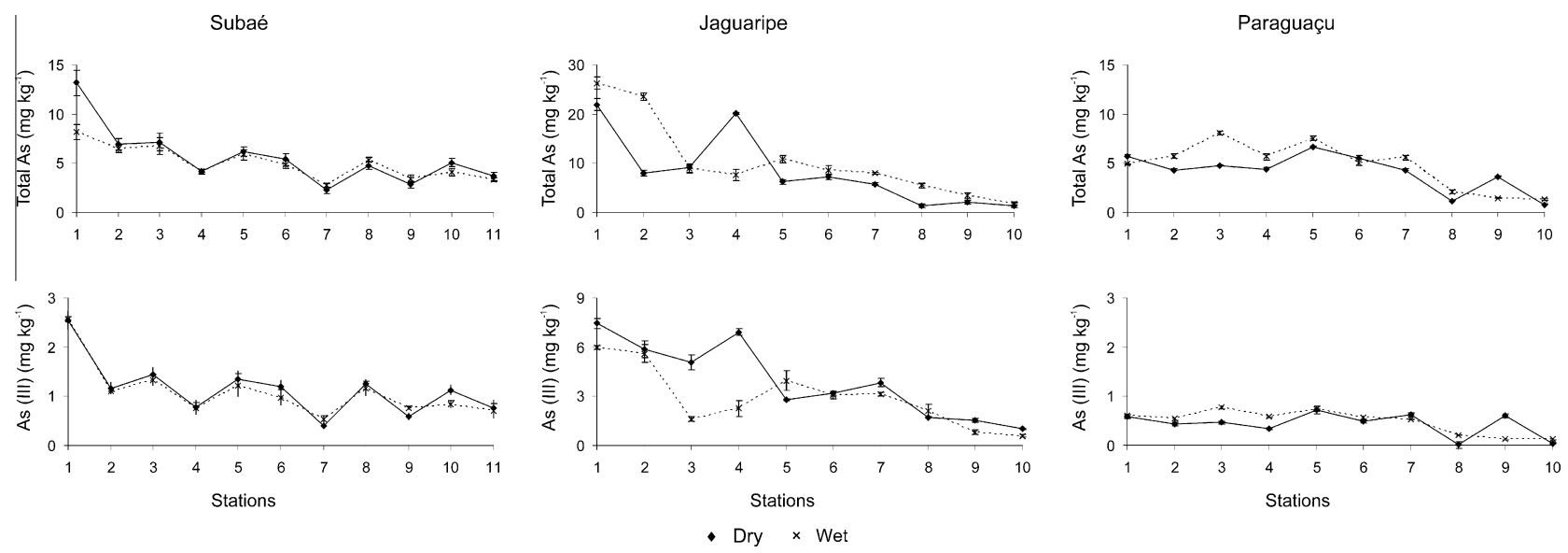

Fig. 5. Total As and As (III) concentrations in the sediment of Todos os Santos bay tributaries, Bahia, Brazil, under dry and wet conditions.

as the distance from the sampling site to the BTS decreased; Fig. 5), whereas the granulometry of the entire estuary was uniform (Fig. 4) and dominated by sand. Bittencourt et al. (1976), Dias (2003) and Cirano and Lessa (2007) found that siliciclastic sand is prevalent at the entrance channels of the bay, along the western border of the BTS and the river mouths. The sand inside Itaparica channel and along the western edge of the bay is composed of quartz grains covered by a clay film (Vilas Boas and Bittencourt, 1979). The clay film is composed primarily of kaolinite, while illite and montmorillonite are found in small amounts (Vilas Boas and Bittencourt, 1979). According to Hartley et al. (2004), arsenic has a short residence time in sand, especially under alkaline conditions, but this does not seems to be the case at Jaguaripe estuary.

Compared to continental deposits, the high concentration of As in marine sediments can be explained by the retention of negatively charged As species (arsenites and arsenates) by iron (oxyhydr)oxides under oxidising, low alkaline conditions (Pierce and Moore, 1982; Baeyens et al., 2007; Mirlean et al., 2010). Thus, the fate of As in sediments may be linked to the stability of $\mathrm{Fe}^{3+}$ hydroxides. Along Espírito Santo coast, south of Bahia state, relatively high As concentrations were observed in marine sediments, and As concentrations were strongly correlated with the sand content (CEPEMAR, 2008). The background As concentration of this region was estimated to be $54.3 \mathrm{mg} \mathrm{kg}^{-1}$, and the elevated As levels observed in the sediments were attributed to lithogenic sources (CEPEMAR, 2008). Experimental data and field studies indicated that arsenic anomalies in sediments were formed when weathered continental rocks enriched with As were leached by marine water. After the release of As from iron (oxyhydr)oxides in subsurface sediments under reducing conditions, the As was retained by biogenic calcareous detritus in near shore sediments (Mirlean et al., 2003; Mirlean et al., 2010). The carbonate content in the northwest and western areas of BTS is low ( $<15 \%$; Lessa et al., 2000). Moreover, the carbonate present in this region is composed primarily of ostracodes, mollusks and equinoderms.

Subaé estuarine sediments also displayed an increase in the total As concentration as the distance to the mouth of the estuary decreased. The total As concentration in the Subaé river may be related to the northwest transport of As contaminated sediments, which were derived from the region impacted by the petrochemical industry and an inactive $\mathrm{Pb}$ smelter that introduced material contaminated with $\mathrm{As}, \mathrm{Cd}, \mathrm{Pb}$ and $\mathrm{Zn}$ into the Subaé River for almost 20 years (CRA, 2004; Hatje et al., 2006). In the Paraguaçu estuary, total As concentrations did not vary significantly along the estuary; however, the results shown in Fig. 5 indicated an apparent increase in total As concentrations as the distance to the estuary mouth decreased. The results of CRA (2004) revealed that relatively high As concentrations were observed in the Itaparica channel, which is south of the mouth of the Paraguaçu estuary.

Fig. 6 shows the ratio of the total As concentration of each sampling site to the concentration of Fe (Hatje et al., in preparation). The results indicated that the As to Fe ratio repeat the pattern observed for the total As concentration. The enhance in the As to $\mathrm{Fe}$ ratio, observed along the estuaries, especially for the Subaé and 


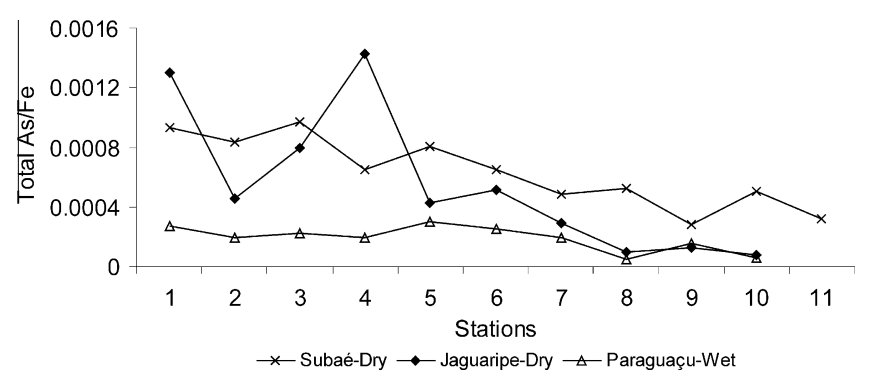

Fig. 6. The ratio of the total As (III) concentration to the Fe concentration in sediments of Todos os Santos bay tributaries, Bahia, Brazil.

Jaguaripe River, suggested that an anomalous source of As was entering into the estuary and increasing the total As concentration. The spatial distribution pattern observed at the tributaries suggested that Todos os Santos Bay may be acting as a source of As. That maybe be a reflection of residual transport of sediment contaminated with arsenic being favoured by the flood tide, resulting in net sediment transport of, possible, enriched marine sediments towards the interior of the estuary. Relatively high concentrations of As can be found in several areas around the BTS (CRA, 2004; Hatje et al., 2009). However, the concentration of As in northern regions is especially high due to anthropogenic activities, such us intensive port activities, petrochemical, chemical, metallurgical and food-related industries concentrated in this region (Hatje et al., 2009).

On the other hand, the vertical distribution of As in the sediment cores collected at several places of the BTS was highly variable (CRA 2004). Relatively high concentrations of As were observed in various cores at different depths, including layers dated back to 1789-1823 (i.e., $30 \mathrm{mg} \mathrm{kg}^{-1}$ ), which were collected from the northern region of the bay. Another sediment core located near the mouth of the Paraguaçu estuarine (close to station 1, (Fig. 1)) displayed top core concentrations up to $50 \mathrm{mg} \mathrm{kg}^{-1}$ and a minimum concentration of $20 \mathrm{mg} \mathrm{kg}^{-1}$ from a layer that was dated back to 1847-1875. Although contemporary As concentrations may be related to anthropogenic activities (especially at Paraguaçu and Subaé estuaries), the data suggested that natural sources of As may be important. Due to the aforementioned results, it is necessary to review the background concentration of As in the study area.

At Jaguaripe estuary, the strong correlation between the total As concentration and the Mn concentration $(p<0.05, r=0.84$; Hatje et al., 2009), as well as the relatively high background of $\mathrm{Mn}$ (344 $\pm 105 \mathrm{mg} \mathrm{kg}^{-1}$; CRA, 2004), corroborated the hypothesis that natural sources of As were important. Similar results were also observed along the coast of Espírito Santo (CEPEMAR, 2008). Additionally, relatively high As concentrations were found all around the bay (Hatje and de Andrade, 2009), suggesting that wet and dry deposition of atmospheric transported As may be playing a role in the distribution of this element in superficial sediments. The most important As inputs to the atmosphere, in Todos os Santos Bay catchment, are from fossil-fuel combustion, smelter and petrochemical operations (Hatje and de Andrade, 2009).

A significant difference in the total As concentration was not observed between the two sampling collections, even though the hydrological conditions during the seasons were distinct.

\subsection{Inorganic arsenic speciation}

A significant proportion of arsenic in sediments is present as As (III) and As (V) (Wang and Mulligan, 2006). The concentration of arsenic (III) in the estuaries is shown in Fig. 5. A longitudinal gradient in the concentrations As (III) was observed in the Jaguaripe and Subaé estuaries, which was similar to the distribution of the total As concentration. In the Paraguaçu River, the distribution of As (III) along the estuary was homogeneous, and significant spatial variability was not observed. Moreover, due to the oxidising conditions of the sediment, As (III) represented less than $17 \%$ of the total arsenic concentration, and As (V) was the predominant form. In the Subaé estuary, As (V) was also the dominant species, representing between $69 \%$ and $83 \%$ of arsenic present in estuarine sediments. Arsenic (V) is less toxic and less mobile than As (III), because As (V) sorbs more strongly to sediment (Pierce and Moore, 1982). Adsorption is one of the most important immobilisation processes of arsenic (Matera et al., 2003), and the adsorption capacity of a particular sediment is dependent on physico-chemical factors such as the $\mathrm{pH}$, Eh, and degree of hydration (Sadiq, 1997). At the $\mathrm{pH}$ range of the sediments in the Subaé (6.9-10) and Paraguaçu (6.8-8.1) estuary, As preferentially sorbs onto Fe and Mn (oxyhydr)oxides, which are widely available. The ratio of As (III)/total As did not vary along the Paraguaçu and Subaé estuaries; thus, As (III) and As (V) behave similarly, and the extent of changes of both species in the water column (i.e., dissolved species) were comparable.

In the sediments of the Jaguaripe River, the percentage of As (III) reached up to $73 \%$ of the total As concentration, indicating that the processes that control the As concentration in this tributary are different from the processes in other studied areas. The concentration and relative proportion of As (V) and As (III) varies with the input source, redox conditions, season and biological activity. Moreover, As (III) may be maintained in oxic waters by biological reduction of As (V). The results suggested that As (III) in the mouth of the Jaguaripe estuary accumulated in the uppermost layer of sediment through a reduction or a decomposition process, and entered the water column through water-sediment exchange. The increase in the proportion of As (III), may, however be rationalized by considering the different adsorptive behavior exhibited by As (III) and As (V) on (oxyhydr)oxides (Gault et al., 2003). The degree and rate of As (III) and As (V) adsorption are dependent upon the water chemistry and the concentration of dissolved As. Studies have shown that the adsorption of As (V) is faster than the adsorption of As (III) (Pierce and Moore, 1982). Arsenic speciation in sediments is a challenging task and is important when relatively high concentrations of As (III) (i.e., above the TEL values) are observed because this form of As poses a significant health risk to human beings.

To exert its toxic effects, arsenic must be liberated from ingested matrices, such as sediments and contaminated invertebrates, to the circulatory system of the host organism (Caussy, 2003). Marine invertebrates are the main source of protein to the large costal population that lives in the BTS catchment area, especially around the Subaé estuary (Hatje et al., 2006; Soares et al., 2009). The concentration of As in marine invertebrates (deposit and filter feeders) in the study area varied from 0.09 to $23 \mathrm{mg} \mathrm{kg}^{-1}$ (CRA, 2004; Santil, 2010). Theses results suggested that As is relatively mobile and bioavailable to benthic organisms. The arsenic that accumulates in marine organisms is typically organic, which is less harmful to human health than other forms of arsenic. Nevertheless, a noncarcinogenic screening risk assessment, due to the ingestion marine invertebrates contaminated by minor and major elements, realised at Todos os Santos Bay, showed that samples of clams, mussels and oysters might pose human health risk due to the As concentrations (CRA, 2005; Souza, 2010). The relatively high concentrations of As (III) indicate that the speciation of arsenic in marine invertebrates should be investigated.

\section{Conclusion}

The total concentration of As at several stations along the studied estuaries was above the recommended value (i.e. TEL and PEL); 
thus, the sediments of these estuaries may be toxic to sensitive bentic species. In the Subaé and Paraguaçu River, As (V) was the dominant species, which is less toxic and less mobile than As (III). Nevertheless, in the Jaguaripe estuary, arsenic concentrations were higher than in other estuaries, and As (III) was the dominant species. The observed relationship between As, Fe, Mn and sand suggested that As in the Jaguaripe River may be naturally occurring. Furthermore, it is possible that at least part of the arsenic in the Paraguaçu estuary is also derived from a natural source. In conclusion, knowledge of the spatial distribution and speciation of arsenic provided information on the mobility and possible toxicity of this contaminant, which can be used to properly manage environmental heath risks.

\section{Acknowledgments}

V. Hatje and S.L.C. Ferreira were sponsored by CNPq-Brazil. This work was supported by FAPESB (CVN 0049/2008) and CNPq (479669/2007-4). The authors would like to thank J.B. de Andrade for his comments on this manuscript, and K.S. Garcia and A.F. de Queiroz for the use of the facilities at the Núcleo de Estudos Ambientais (NEA).

\section{References}

Amado Filho, G.M., Salgado, L.T., Rebelo, M.F., Rezende, C.E., Karez, C.S., Pfeiffer, W.C., 2008. Heavy metals in benthic organisms from Todos os Santos Bay, Brazil. Brazilian Journal of Biology 68 (1), 95-100.

Baeyens, W., de Brauwere, A., Brion, N., De Gieter, M., Leemarers, M., 2007. Arsenic speciation in the River Zenne, Belgium. Science of the Total Environment 384, 409-419.

Barros, F., Hatje, V., Figueiredo, M.B., Magalhães, W.F., 2008. The structure of the benthic macrofaunal assemblages and sediments characteristics of the Paraguaçu estuarine system, NE, Brazil. Estuarine, Coastal and Shelf Science 78, 753-762.

Bittencourt, A.C.da Silva, Ferreira, Y.de A.F., di Napoli, E., 1976. Alguns aspectos da sedimentação na Baía de Todos os Santos, Bahia. Revista Brasileira de Geociências 6, 246-263.

Cal-Pietro, M.J., Felipe-Sotelo, M., Carlosena, A., Andrade, J.M., Lopez-Mahia, P., Muniategui, S., Prada, D., 2002. Slurry sampling for direct analysis of solid materials by electrothermal atomic absorption spectrometry (ETAAS). a literature review from 1990 to 2000. Talanta 56, 1-51.

Caussy, D., 2003. Case studies of the impact of understanding bioavailability: arsenic. Ecotoxicology and Environmental Safety 56, 164-173.

CEPEMAR, 2008. Diagnóstico da contaminação por As nos sedimentos na área do entorno Portocel, em Aracruz-ES. Relatório técnico final COM RT 489/08, pp. 90.

Chapagain, S.K., Shrestha, S., Du Laing, G., Verloo, M., Kazama, F., 2009. Spatial distribution of arsenic in the intertidal sediments of River Scheldt, Belgium. Environment International 35 (3), 461-465.

Cirano, M., Lessa, G.C., 2007. Oceanographic characteristics of Baía de Todos os Santos, Bahia. Revista Brasileira de Geofísica 25, 363-387.

Costa, L.M., Santos, D.C.M.B., Hatje, V., Nóbrega, J.A., Korn, M.G., 2009. Focusedmicrowave-assisted acid digestion: Evaluation of losses of volatile elements in marine invertebrate samples. Journal of Food Composition and Analysis 22, 238-241.

CRA, 2004. Diagnóstico ambiental do grau de contaminação da Baía de Todos os Santos por metais pesados e hidrocarbonetos. Consórcio BTS Hydros CH2MHILL. CRA, Salvador.

CRA, 2005. Análise preliminar de risco à saúde humana. Complementação do Diagnóstico do grau de contaminação da Baía de Todos os Santos por metais pesados e hidrocarbonetos de petróleo a partir da análise das suas concentrações nos sedimentos de fundo e na biota associada Relatório final. vol. I. Consórcio BTS Hydros CH2MHILL. CRA, Salvador.

CRA, 2008. Inventário de atividades com potencial de contaminação/poluição e de produtos químicos na Baía de Todos os Santos. Tomo I - Relatório Preliminar. HYDROS Engenharia e Planejamento Ltda. Tomo I. Governo do Estado da Bahia, pp. 269.

da Rocha, G.O., Lopes, W.A., Pereira, P.A.de P., Oliveira, F.S., Carvalho, L.S., Conceicao, L. dos S., de Andrade, J.B., 2009. Atmospheric particulate polycyclic aromatic hydrocarbons and their dry deposition fluxes at three sites in Salvador Basin, Brazil, impacted by mobile and stationary sources. Journal of Brazilian Chemical Society 20,680-692.

Datta, R., Markris, K.C., Sarkar, D., 2007. Arsenic fractionation and bioaccessibility in two alkaline Texas soils incubated with sodium arsenate. Archives of Environmental Contamination and Toxicology 52, 475-482.

Dias, K., 2003. Reavaliação da distribuição especial das fácies texturais do leito da Baía de Todos os Santos. Monografia de conclusão de curso. Curso de Geologia, Universidade Federal da Bahia, Brasil. pp. 50
Gault, A.G., Polya, D.A., Lythgoe, P.R., Farquhar, M.L., Charnock, J.M., Wogelius, R.A., 2003. Arsenic speciation in surface waters and sediments in a contaminated waterway: an IC-ICP-MS and XAS based study. Applied Geochemistry 18, 13871397.

Genz, F., 2006. Avaliação dos efeitos da Barragem de Pedra do Cavalo sobre a circulação estuarina do Rio Paraguaçu e Baía de Iguape, Doctor's Thesis, Universidade Federal da Bahia, pp. 266.

Giacomino, A., Malandrino, M., Abollino, O., Velayutham, M., Chinnathangavel, T., Mentasti, E., 2010. An approach for arsenic in a contaminated soil: speciation, fractionation, extraction and effluent decontamination. Environmental Pollution 158, 416-423.

Gray, J.R., Khalil, A., Prior, J.C., 1989. Acute arsenic toxicity: an opaque poison. Journal of the Canadian Association of Radiologists 40, 226-227.

Hartley, W., Edwards, R., Lepp, N.W., 2004. Arsenic and heavy metal mobility in iron oxide-amended contaminated soils as evaluated by short- and long-term leaching test. Environmental Pollution 131, 495-504.

Hatje, V., Barros, F., Figueiredo, D.G., Santos, V.L.C.S., Peso-Aguiar, M.C., 2006. Trace metal contamination and benthic assemblages in Subaé estuarine system, Brazil. Marine Pollution Bulletin 52, 969-987.

Hatje, V., de Andrade, J.B. (Eds.), 2009. Baía de Todos os Santos: aspectos oceanográficos. Edufba, Salvador. pp.304.

Hatje, V., Bícego, M.C., Carvalho, G.C., de Andrade, J.B. de, 2009. Contaminação Química. In: Hatje, V., de Andrade, J.B. (Eds.), Baía de Todos os Santos: aspectos oceanográficos. Edufba, Salvador, pp. 243-299.

Hatje, V., Barros, F., Lessa, G.C., in preparation. Fluxes and geochemistry of the main tributaries of Todos os Santos Bay, BA, Brazil.

Hughes, M.F., 2002. Arsenic toxicity and potential mechanisms of action. Toxicology Letters 133, 1-16.

IUPAC, 1994. Analytical Methods Committee. Analyst 119, 16-32.

Ko, I., Kim, J.Y., Kim, K.W., 2004. Arsenic speciation and sorption kinetics in the Ashematite-humic acid system. Colloids and Surfaces A: Physicochemical and Engineering Aspects 234, 43-50.

Lessa, G.C., Bittencourt, A.C.S.P., Britcha, A., Dominguez, J.M.L., 2000. A reevaluation of the late quaternary sedimentation in Todos os Santos Bay (BA), Brazil. Anais da Academia Brasileira de Ciências 72, 573-590.

Luoma, S.N., Rainbow, P.S., 2008. Metal contamination in aquatic environments. Cambridge University Press, Cambridge. pp. 573.

Macedo, S.M., de Jesus, R.M., Garcia, K.S., Hatje, V., Queiroz, A.F.S., Ferreira, S.L.C., 2009. Determination of total arsenic and arsenic (III) in phosphate fertilizers and phosphate rocks by HG AAS after multivariate optimization based on BoxBehnken design. Talanta 80, 974-979.

Matera, V., Le Hécho, I., Laboudigue, A., Thomas, P., Tellier, S., Astruc, M., 2003. A methodological approach for the identification of As bearing phases in polluted soils. Environmental Pollution 126, 51-64.

Mirlean, N., Andrus, V.E., Baisch, P., Griep, G., Casartelli, M.R., 2003. Arsenic pollution in Patos Lagoon estuarine sediments, Brazil. Marine Pollution Bulletin $46,1480-1484$

Mirlean, N., Baisch, P., Travassos, M.P., Nassar, C., in press. Calcareous algae contribution to sediment enrichment by arsenic on the Brazilian subtropical coast. Geo-Marine Letters.

Nacional Research Council, 1999. Arsenic in drinking water. Nacional Academic Press, Washington, DC.

NOAA. 2004. Screening quick reference tables. Hazmat Report, vol. 99, no. 1, National Academy Press, Washington, pp. 601.

Ollson, C.C., 1999. Arsenic contamination of terrestrial and freshwater environmental impacted by gold mine operations Yellowknife, NWT. Thesis. Royal Military College of Canada, Keingston, Canada.

Pereira, P.A.de P., Lopes, W.A., Carvalho, L.S., da Rocha, G.O., de Carvalho Bahia, N., Loyola, J. Quiterio, S.L. Escaleira, V., Arbilla, G. de Andrade, J.B. 2007. Atmospheric concentrations and dry deposition fluxes of particulate trace metals in Salvador, Bahia, Brazil. Atmospheric Environment 41 (36), 78377850.

PETROBRAS/FUNDESPA, 2003. Diagnóstico Ambiental Marinho da Área de Influência da Refinaria Landulpho Alves Mataripe-DAMARLAM. Relatório Final, São Paulo, FUNDESPA.

Pierce, M.L., Moore, C.B., 1982. Adsorption of arsenite and arsenate on amorphous iron hydroxide. Water Research 16, 1247-1253.

Plant, J.A., Kinniburgh, D.G., Smedley, P.L., Fordyce, F.M., Klinck, B.A., 2005. Arsenic and Selenium. In: Lollar, B.S. (Ed.), Environmental Geochemistry. Treatise on Geochemistry, vol. 9. Elsevier-Pergamon, Oxford, pp. 17-66.

Quevauviller, P., Rauret, G., Muntau, H., Ure, A.M., Rubio, R., López-Sánchez, J.F., Fielder, H.D., Griepink, B., 1994. Evaluation of a sequential extraction procedure for the determination of extractable trace-metal contents in sediments. Journal of Analytical Chemistry 349, 808-814.

Razo, I., Carrizales, L., Castro, J., Díaz-Barriga, F., Monroy, M., 2004. Arsenic and heavy metal pollution of soil, water and sediments in a semi-arid climate mining area in Mexico. Water, Air, and Soil Pollution 152, 129-152.

Reis, J.O.N., 1975. Determinação polarográfica de $\mathrm{Pb}^{2+}$ and $\mathrm{Cd}^{2+}$ em águas do Rio Subaé, Santo Amaro, Bahia. Master's Thesis. Universidade Federal da Bahia, Salvador, pp. 81.

Rittle, K.A., Drever, J.I., Colberg, P.J.S., 1995. Precipitation of As during bacterial sulphate reduction. Geomicrobiology Journal 13, 1-11.

Sadiq, M., 1997. Arsenic chemistry in soils: Na overview of thermodynamic predictions and Field observations. Water, Air, and Soil Pollution 93, 117-136.

Saha, K.C., 2003. Review of arsenicosis in West Bengal, India: a clinical perspective. Critical Reviews in Environmental Science and Technology 30, 127-163. 
Santil, D. da S., 2010. Determinação de metais majoritários e elementos traços em tecidos de moluscos bivalves por espectrometria de emissão óptica com plasma indutivamente acoplado. Master's Thesis. Universidade Federal da Bahia, Brasil, pp. 130.

Santos, M.C., Nóbrega, J.A., 2006. Slurry nebulization in plasmas for analysis of inorganic materials. Applied Spectroscopy Reviews 41, 427-448.

Senesse, P., Justrabo, E., Boschi, F., Goegebeur, G., Collet, E., Boutron, M.C., 1999. Cronkhite-Canada syndrome and arsenic poisoning: fortuitous association or new etiological hypothesis? Gastroenterologie Clinique et Biologique 23, 399402.

Soares, LS.H., Salles, A.C.R., Lopes, J.P., Muto, E.Y, Giannini, R, 2009. Pesca Produção Pesqueira. In: Hatje, V., de Andrade, J.B. (Eds.), Baía de Todos os Santos: aspectos oceanográficos. Edufba, Salvador, pp. 157-206.

Souza, M.C.M.B.N de, 2010. Avaliação em nível de rastreamento do risco toxicológico para a saúde humana por ingestão de invertebrados marinhos: Baía de Todos os Santos, BA, Brazil. Honour's Thesis. Universidade Federal da Bahia, Brasil, pp. 87.

Tessier, A., Campbell, P.G.C., Bisson, M., 1979. Sequential extraction procedure for the speciation of particulate trace metals. Analytical Chemistry 51, 844-851.

Tomkins, A.G., Frost, B.R., Pattison, D.R.M., 2006. Arsenopyrite melting during metamorphism of sulfide ore deposits. The Canadian Mineralogist 44, 10451062.

USEPA (U.S. Environmental Protection Agency), 1998. Integrated risk information system (IRIS): arsenic, inorganic. CASRN 7440-38-2, Cincinnati, OH.

Vale, M.G.R., Oleszczuk, N., dos Santos, W.N.L., 2006. Current status of direct solid sampling for electrothermal atomic absorption spectrometry - a critical review of the development between 1995 and 2005. Applied Spectroscopy Reviews 41, 377-400.

Venturini, N., Bícego, M.C., Martins, C.C., 2004. Characterization of the benthic environment of a coastal area adjacent to an oil refinery, Todos os Santos Bay (NEBrazil). Brazilian Journal of Oceanography 52, 123-134.

Venturini, N., Muniz, P., Bícego, M.C., Martins, C.C., Tommasi, L.R., 2008. Petroleum contamination impact on macrobenthic communities under the influence of an oil refinery: integrating chemical and biological multivariate data. Estuarine, Coastal and Shelf Science 78, 457-467.

Vilas Boas, G. da S., Bittencourt, A.C. da S.P., 1979. Mineralogia e composição química da fração argilosa dos sedimentos do fundo da Baía de Todos os Santos, Bahia. Revista Brasileira de Geociências 9, 179-197.

Wallner-Kersanach, M., Theede, H., Eversberg, U., Lobo, S., 2000. Accumulation and elimination of trace metals in a transplantation experiment with Crassostrea rhizophorae. Archives of Environmental Contamination and Toxicology 38 (1) 40-45.

Wang, S., Mulligan, C.N., 2006. Occurrence of arsenic concentration in Canada: sources, behavior and distribution. Science of the Total Environment 366, 701721.

Webster, J.G., 1999. Encyclopaedia of geochemistry. In: Mrshall, C.P., Fairbridge, R.W. (Eds.). Chapman Hall, London, pp. 21-22.

WHO, 1993. Guidelines for drinking water quality, second ed.. Recommendations, World Health Organization.

Zheng, J., Hintelmann, H., Dimock, B., Dzurko, M.S., 2003. Speciation of As in water sediment, and plants of the Moira watershed, Canada, using HPLC coupled to high resolution ICP-MS. Analytical and Bioanalytical Chemistry 377, 14-24. 